\title{
GREEN AND SUSTAINABILITY CRITERIA IN MALAYSIA'S POULTRY PRODUCTION AND MANAGEMENT
}

\author{
RAHMAT SUHARNI, BOON CHEONG CHEW AND ABDUL HAMID MOHD SAIFUL RIZAL* \\ Faculty of Technology Management and Technopreneurship, Universiti Teknikal Malaysia Melaka, Hang Tuah Jaya, Durian \\ Tunggal, 76100 Melaka, Malaysia.
}

*Corresponding author: suharnirahmat@gmail.com

Submitted final draft: 3 September $2020 \quad$ Accepted: 5 September $2020 \quad$ http://doi.org/10.46754/jssm.2021.07.011

\begin{abstract}
This article discusses green and sustainability (G\&S) criteria in poultry production in Malaysia. The study focuses on broiler production management from the downstream (farm management) to the upstream (end-user) processes. This study is important as it investigates new developments of the poultry industry in Malaysia. As this is an exploratory study, the study is conducted based on a case study of oa halal broiler company in Malaysia. Data was gathered through semi-structured interviews and observations of nine government agencies in Malaysia that are involved in poultry production. Thematic analysis and patterns were applied in analysing the data. The results show the G\&S criteria described in the regulations and production process perspective. The four G\&S criteria listed in the category of poultry content are: i) effective use of technology; ii) enhancing nutrition; iii) sustainable sourcing; and, iv) improving land and water management.
\end{abstract}

Keywords: Sustainability criteria, green food criteria, food production, poultry production, Malaysia.

Abbreviations: G\&S - Green and Sustainability.

\section{Introduction}

The poultry industry in Malaysia has shown rapid progress compared with other livestock industries. Hashim (2015) reported that poultry production in Malaysia exceeded local demand and was capable of being exported to another country. According to the Federation of Livestock Farmers' Associations of Malaysia (FLFAM, 2016) poultry meat (including chicken and duck meat) had a total output of RM10.26 billion.

As Malaysia aims to export at least 30 per cent of broiler chickens by 2030, the then deputy prime minister claimed that the level of sufficiency for poultry in Malaysia was $128 \%$ and contributed to 75 per cent of national livestock industry (The Poultry Site, 2017). Thus, it would be worth it for the poultry market to invest in new development.

In Malaysia, the poultry (chicken) industry is divided into two major productions: broiler production and eggs production. There are four grandparent (GP) and 22 parent stock
(PS) farms for broiler production and five layers of PS companies for eggs production \in Peninsular Malaysia (FLFAM,2016). Singapore is a potential market for both broiler and eggs for the country.

\section{The Importance Implementing Green and Sustainability in Poultry Production}

In poultry production, most scholars illustrate G\&S in the agriculture and livestock contexts, especially in the environment, social and economic aspects. Burch et al. (2006) stated G\&S is the process of change in the ideologies and practices into the environmental concerns. It includes non-polluting practices, reducing non-chemical inputs in production systems and relying on ecological farming techniques. Martin \& Kadokawa (2006) described G\&S as "clean, sector green and ethical" practices to improve reproductive performance, while Battaglia (2014) and Watson \& Schlotzer (2017) related the definition of G\&S with animal rights and welfare as parts of G\&S that people need to care and respect. Ali \& Suleiman (2016) 
described G\&S in the context of set food activities as healthy to be consumed, minimises any environmental effects, use fewer chemicals, apply food safety and keep the environment safe, implement high standards of animal rearing, including taking care of their health and welfare, and a having a better workplace for employees. As the food system becomes advanced, elements such as resource efficiency, profitability, productivity, environmental soundness, biodiversity, social viability and ethical aspects are needed in the food activity, especially when it relates to livestock (Olesen et al., 2000).

However, changes in the food system becomes a concern when it involves greenhouse gases (GHG) emission (Sonigo et al., 2012; Garnett, 2013) and most food processing nowadays use modern technology, which may affect their nutritional value at this stage as observed by many scholars. For instance, minimising or controlling the use of preservatives in maintaining food nutrition (Mirza et al., 2017). Though, in other circumstance, modern technologies may promise energy efficiency, water savings and reduced emissions (Pereira \& Vicente, 2010). In other words, G\&S in the food system include the environmental, social and economic sectors as illustrated in Figure 1.

The G\&S implementation could bring benefits to the poultry industry with regards to the environmental, social and economic aspects. In the environmental aspect, Vaarst et al. (2015) reported that poultry farms have a lower impact in terms of land size, water use, environmental stress and footprints among all livestock farms. Röös et al. (2017)the weight accorded to these depends on one's view of what the priority goals are for the food system and the extent to which production systems versus consumption patterns are open to change. Some stakeholders see the problem as one of 'not enough food' and focus on the need to sustainably increase supply, while others consider the resource demanding and 'greedy' consumption patterns of the Western world as the main problem and emphasize the need to shift diets. In this study global land use and greenhouse gas emissions are estimated for a set of scenarios, building on four 'livestock futures' reflecting these different perspectives. These scenarios are: further intensification of livestock systems; a transition to plant-based eating; a move towards artificial meat and dairy; and a future in which livestock production is restricted to the use of 'ecological leftovers' i.e. grass from pastures, food waste and food and agricultural byproducts. Two dietary variants for each scenario are modelled: 1 also agree that poultry farming utilises smaller land sizes and has a low waste level compared with other livestock farming. Besides, G\&S implementation could slow down the natural ecosystems processes and protect biodiversity and promote the effective use of natural resources (Dicks et al.,2013).

In terms of the social aspect, poultry meat provides protein, which people need as a source of energy; and as poultry meat is recognised as a high-quality food, the global demand for this animal product have increased (Makkar,

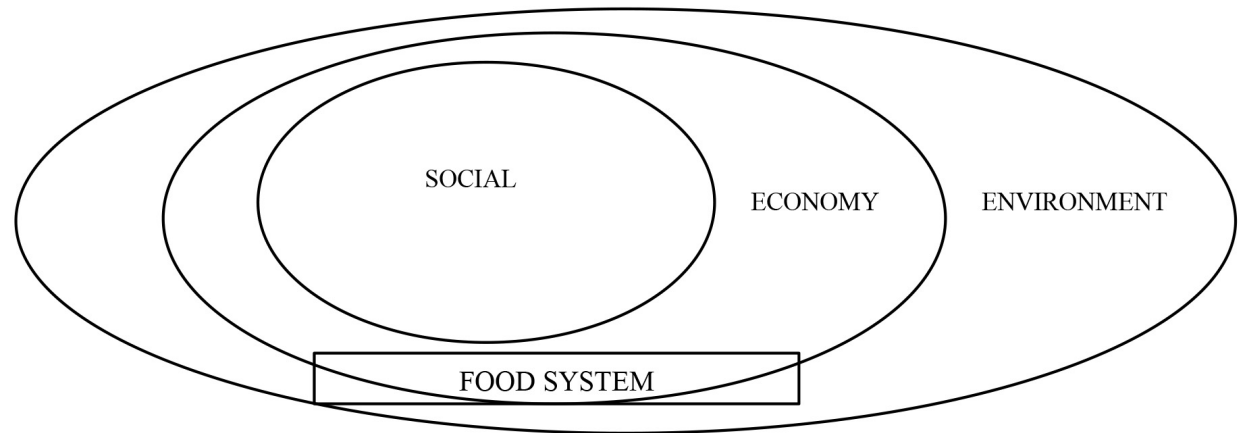

Figure 1: The relationship between the food system process and green and sustainability 
2016; Van Kernebeek et al., 2016; Reynolds et al., 2015; Mohd Syauqi et al., 2015; Sharaai et al., 2015; Leip et al., 2015)we need to focus on increasing land pro-ductivity, reducing waste, and shifting human diets. Studies exploring diet shifts so far have ignored competition for land between humans and animals. Our objective was to study the relation between land use, the share of animal protein in the human diet, population size, and land availability and quality. Methods We used linear programming to determine minimum land required to feed a population a diet with $0-80 \%$ of the protein derived from terrestrial domestic animals. Populations ranged from 15 million to the maximum number of people that could be supported by the system. The agricultural system in the Netherlands was used as illustration, assuming no im-port and export of feed and food. Daily energy and protein requirements of humans were fulfilled by a diet potentially consisting of grain (wheat due to the high income of the global population and their awareness of the benefits of consuming healthy quality food. Furthermore, according to the Association of Poultry Processors and Poultry Trade in the EU Countries (2016) poultry meat has an advantage over other meats, which are affordability, convenience, absence of religion guidelines limiting consumption, healthy image, reduced GHG emissions and lower production costs.

From the economic aspect, manure from the poultry can be used as fertilisers and other by-products. Reynolds et al. (2015) reported that poultry production brings high profit to food industries. Besides, livestock industries recorded the poultry industry as progressive in terms of providing protein meat and being affordable compared with other livestock industries (Elsedig et al., 2015; Federation of Livestock Farmers' Associations of Malaysia, 2016). The Department of Veterinary Services (2016) and Chin (2017) reported that the average consumption of chicken meat in Malaysia is 45 $\mathrm{kg}$ to $50 \mathrm{~kg}$ per person annually. It shows that there is always domestic demand for poultry. In addition, the Trade Map in the International Trade Centre (Workman, 2018) also reported that the global sales for fresh chicken shipments amounted to US\$5.9billion (RM23.6 billion) in 2017.

\section{Green and Sustainability in Food System Framework}

The food system is a set of activities involved in providing food for necessities (Meullenet, 2013) as shown in Figure 2, which are production, processing, distribution and consumption. The food system set activities are expanding due to the current food trends that include G\&S practices as part of the food system (Devendra, 2015)improved livelihoods and increased prosperity in Asia. Feed resources, the primary determinant of productivity, are most important, but are constrained to drive the supply of animal proteins. Currently the scenario is challenged by at least four defining factors: (i. Westhoek et al. (2016) state that food system activities (refer Figure 2) might be longer and are influenced by participation from producers, institutions, and are engaged with other production chains and relationships. The involvement of other parties (producers and institutions) will develop and deliver long-process inputs to the farming sector by producing primary supplies, subsequent handling, processing, transportation, marketing and distribution of food and other agro-based products to consumers. Thus, Figure 2 explains the poultry production and management process consisting of production, processing, distribution and consumption.

\section{Green and Sustainability Criteria}

According to Power et al. (2012), G\&S could be developed through five pillars: improving land and water management, enhancing nutrition, effectively using technology, sustainable sourcing and reducing commodity price volatilityThe five pillars are explained below based on the environmental, social and economic sectors:

Improving Land and Water Management

Power et al. (2012) suggest that land and water management are conserved through education 


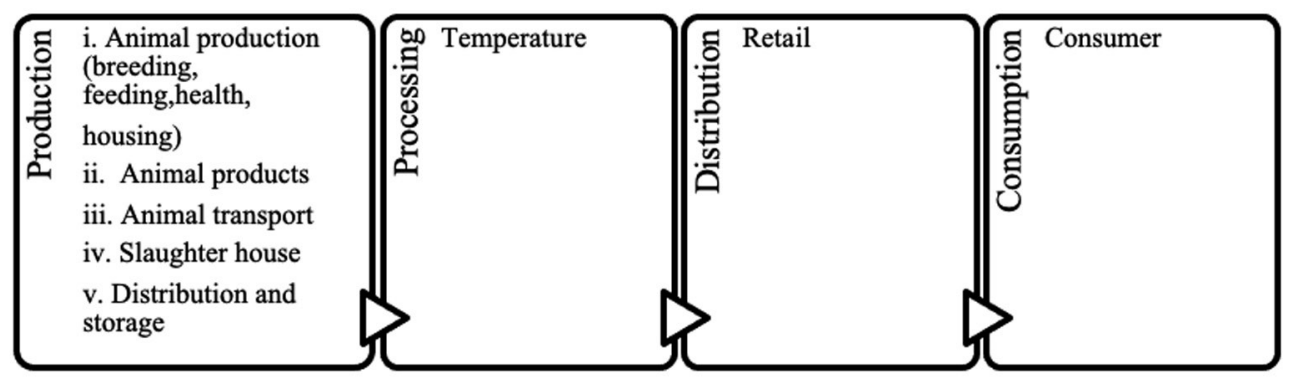

Figure 2: Poultry production and management process in the food system

and training. To implement G\&S, land and water management must engage with the environmental and economic sectors. Both sectors are needed in better farming practices by improving the process and reversing the process of soil degradation, including water treatment, which could save energy. This method needs people and workers who can operate a water system. Besides, W.Blevins (2013) stated that food industries employed food safety and regulatory compliance specialists and food scientists to innovate and collaborate with the food production industry to better manage land and water resources. However, workers' knowledge is the main criteria in mastering and understanding that quality equals conformance to requirements in food industries (Luning \& Marcelis, 2009).

\section{Enhancing Nutrition}

To enhance nutrition, Power et al. (2012) recommend providing affordable and nutritious food products. It can be implemented through an alliance with governments, civil society and food production for environmental and social benefits. These parties need to work together to focus on not merely increasing the production quality of food and access globally, but increasing the nutritional quality of food and consumer access.

The criteria of G\&S highlighted in a consumer context are quality food products, healthy food and fresh and natural food products. As demand for animal products increases due to the growing population, economics and change in dietary needs, and the way how society consume food need to take into consideration. Scholars mentioned that consumer have an awareness of G\&S production. For instance, Chen \& Chang (2013)this study seeks to elaborate the relationships among green perceived quality, green perceived risk, green satisfaction, and green trust. Design/methodology/approach The research object of this paper focuses on Taiwan's consumers who have the purchase experience of information and electronics products. This study undertakes an empirical study by means of the questionnaire survey method. The questionnaires were randomly mailed to consumers who had the purchase experience of information and electronics products. Structural equation modeling (SEM state that consumer perceived green product qualities as having a positive influence on green satisfaction and green trust. In the same vein, Zikeli et al. (2014) and Murdoch et al. (2016) noted that green products contribute to diet changes as the population are concerned about healthy food. Furthermore, Luning (2002) stated that consumers are seeking food that are "fresher", and are enhanced with natural flavours and use less harsh processing and production. Thus, awareness among consumers of health, safety and quality food products contributes to the choices of green food products.

To enhance nutrition, food producers must increase availability, affordability, and consumption of diverse, safe, and nutritious food and diets to develop G\&S (FAO, 2015).

Besides, the government needs to play its role. Power et al. (2012) states that nutrition can enhance by developing policies and regulations 
to install local food quality control systems and the use of enhanced fertilisers by using nutritious inputs in nutrient-rich seeds and micronutrients. FAO (2015) also agrees that livestock programmes and investments need to be supported by an enabling policy environment if they are to contribute to improving nutrition.

\section{Effectively using Technology}

The effective use of technology is discussed in two forms: improving productive assets and resource efficiency. Both ideas relate to the environmental and economic sectors. Improved productive assets lead to innovation and costeffective technologies and technological advancements with low environmental impacts. Olesen et al. (2000); Power et al. (2012); Shen et al. (2013); and Evans \& Syed (2015) supported that innovation and anything applicable to costeffective technology are capable of improving sustainable livestock, including reducing crop loss, distribution networks, market information, and green introduction (Frazer, 2008). Also, costeffective technology development could sustain energy usage, manufacturing, transportation and other economic sectors that have significant environmental impacts (Tilman, 2002).

Resource efficiency explains technological know-hows. However, Frazer (2008) states that the main constraints in adopting livestock technology are capital availability, tehnological know-hows and government policies shielded by the countries.

In terms of capital availability, while many large, highly-capitalised commercial farms benefit from technological advancements, poor smallholder farmers are often too difficult to reach due to expensive equipment and training lack of accessible training or follow-up resources for wide-scale adoption (Power et al., 2012). However, this trend is starting to change as the private sector, civil societies and governments are investing more in technology solutions that could be used in remote areas, are affordable, ecologically sustainable and are packaged with adequate support and follow-up resources for farmers.
In terms of technological know-hows, good worker knowledge is one option (Pacholewicz et al., 2016, which refers to labour efficiency (Ezeh et al., 2012; Makutènienè \& Baležentis, 2015). Even food producers, non-governmental organisations and government agencies demand integration of knowledge from different disciplines to inform policies and practices in the sustainability of livestock feed, tradeoffs between ecosystem services at the farm or landscape scale, phosphorus recycling and metrics to measure sustainability (Dicks et al., 2013). The outcomes will guide ongoing knowledge exchanges, future science policies and funding. Since technological innovation is critical for on-farm use, it can also support more efficient financial transactions, better healthcare, and improved education access.

In other words, using technology effectively in G\&S criteria can be defined as "sustainable use of resources" or "minimising the use of natural resources" (European Environment Agency, 2011); and for the green criteria, which Logaa \& Zailani (2013) describe as minimising waste, conserving and saving energy and improving operational and organisational procedures.

\section{Sustainable Sourcing}

At this point, sustainable sourcing suggests two aspects: selecting supplier and certification scheme policy. It is related to the social and economic sectors. Sustainable sources are needed for global expansion by lowering costs and increasing production capacity. Thus, the process of selecting a supplier is critical. According to Ecovadis (2017), sustainable sourcing is the integration of social, ethical and environmental performance that are involved in the process of selecting suppliers. Power et al. (2012) mentioned that sustainable sourcing is called responsible sourcing or ethical sourcing as it is related to the capability of meeting economic, environmental and social standards in every aspect of the food supply chain to ensure a healthy food and livestock system. However, there is a risk that the food industry needs to take in building strong relationships with suppliers. For this reason, the study management must play 
its roles in selecting a supplier for the long term (Goebel et al., 2012)companies are increasingly being held responsible for the actions of their suppliers. Subsequently, Purchasing and Supply Management (PSM. In terms of the certification scheme, Ross et al. (2015) agree that many agri-food firms are incorporating sustainability initiatives into their business operations as a response to internal and external pressures to achieve cost savings and waste reduction. Power et al. (2012) state that many companies have imposed certification schemes as a way to measure, report and defining sustainability in farming, such as the organic label, fair trade, and rainforest alliance.

Moving towards to G\&S implementation in food production, Mohd Syauqi et al. (2015) reports that animal health management, feed management and biosecurity were among the main concerns of livestock operators as they have an effect on profit and loss achievements. However, Mohd Syauqi et al. (2015) mentioned that many of food industries, especially ivestock production, are incapable of achieving the international standard level in importing products due to low standard requirement, the production cost of imported raw ingredients sources and diseases and poultry welfare. Thus, the implementation of G\&S is worth it in ensuring the food industry is capable of reducing emissions and protect the environment, increase demand and profit.

Furthermore, W.Blevins (2013) mentioned that regulations needed in food industries between operations and management and acted with understanding and commitment will increase company profits and job security for employees.

\section{Reducing Trading Price Instability}

Reducing trading price instability targets the social and economic sectors. It discusses in trend and in food consumption are related to the way the food are produced. According to Power et al. (2012), the way food are produced have an effect on unstable price fluctuations due to global flows in supply and demand as farmers cope with the weather and try to predict future needs. Weather-related incidents, such as droughts, floods and hurricanes, are increasing as climate change leads to more crop losses (Power et al., 2012). Initially, the main factor that contributes to price volatility is the increase in the world's population and the demand for food is expected to increase by between $70 \%$ and $100 \%$. Hence, rising food prices have severely affected income distribution and poverty, especially in lowincome economies (Power et al., 2012).

In other circumstances, trends in food consumptions contribute to changes in global export (Oosterveer \& Sonnenfeld, 2012). However, government export restrictions have also amplified price movements and might provoke price increases (White et al., 2013). Through that, governments, the private sector and civil societies can contribute to reducing commodity price volatility by focusing on constructing policies and investments. Table 1 demonstrates the G\&S development and criteria based the environmental, social and economic sectors, within five pillars.

\section{Green and Sustainability in Poultry Production}

Poultry production and management processes have four main stages. The first stage is primary production; the second is processing; the third is retailing; and the fourth is the consumer.

The primary stage includes breeding, feeding, health and housing activities. After these activities, the poultry goes through animal products, animal transport, slaughterhouse and distribution and storage process. In the first stage of primary production for breeding activities, the literature identifies the G\&S criteria in animal welfare, technological innovation and health and house management, which lead to the improvement of efficiency of livestock production. Based on the five pillars, the G\&S criteria is significant to improve land and water management and effective use of technology for the environmental and economic sector.

For animal feeding activities, the G\&S criteria encompass five pillars as mentioned by Power et al. (2012): enhancing nutrition; 
Table 1: G\&S development and criteria in five pillars

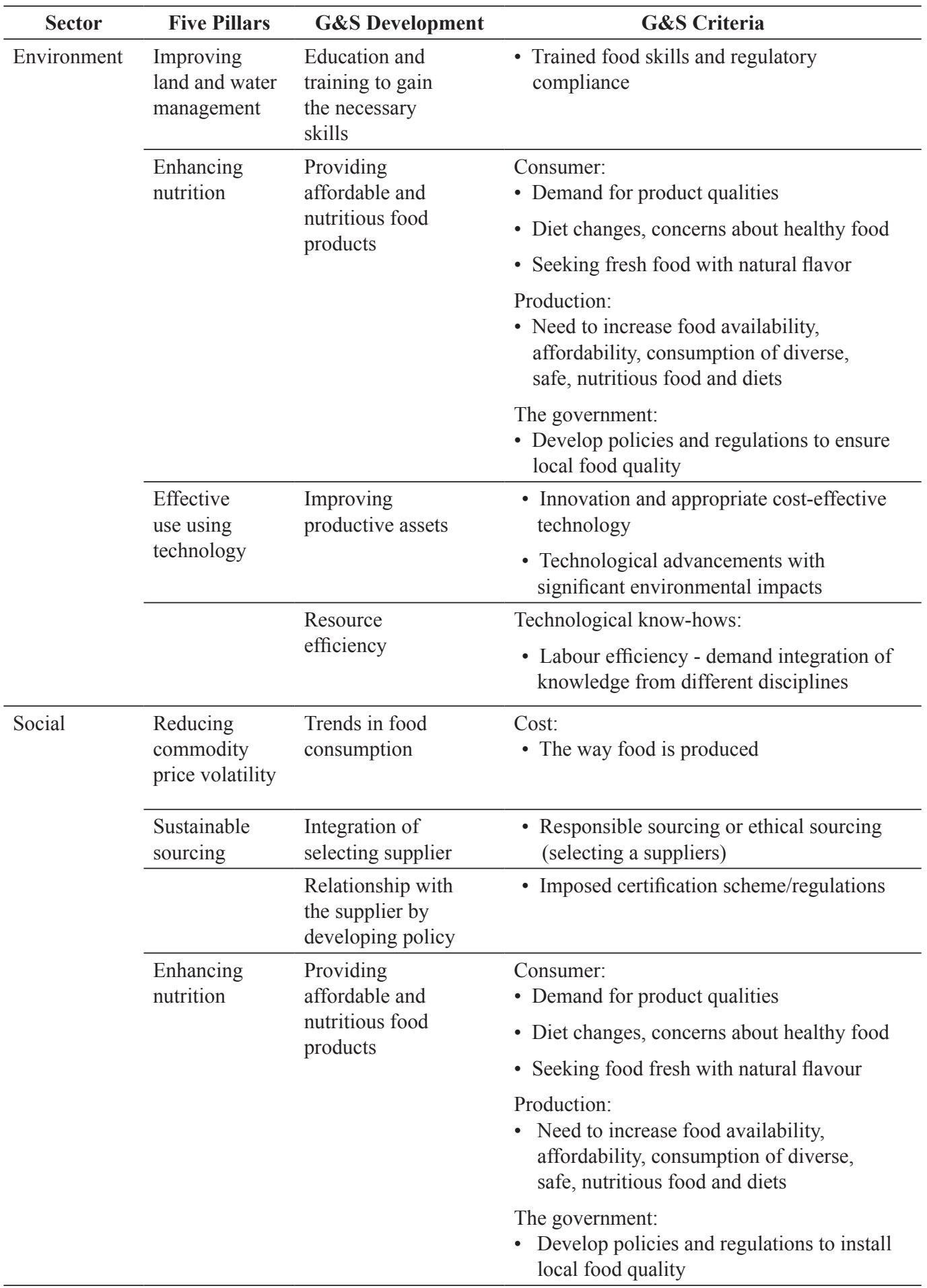




\begin{tabular}{|c|c|c|c|}
\hline \multirow[t]{6}{*}{ Economy } & $\begin{array}{l}\text { Sustainable } \\
\text { sourcing }\end{array}$ & $\begin{array}{l}\text { Integration of } \\
\text { selecting supplier }\end{array}$ & $\begin{array}{l}\text { - Responsible sourcing or ethical sourcing } \\
\text { (selecting suppliers) }\end{array}$ \\
\hline & & $\begin{array}{l}\text { Relationship with } \\
\text { supplier develop } \\
\text { policy }\end{array}$ & - Imposed certification scheme/regulations \\
\hline & $\begin{array}{l}\text { Improving } \\
\text { land and water } \\
\text { management }\end{array}$ & $\begin{array}{l}\text { Education and } \\
\text { training to gain } \\
\text { the necessary } \\
\text { skills }\end{array}$ & $\begin{array}{l}\text { Trained food skills and regulatory } \\
\text { compliance }\end{array}$ \\
\hline & $\begin{array}{l}\text { Effectively } \\
\text { using } \\
\text { technology }\end{array}$ & $\begin{array}{l}\text { Improving } \\
\text { productive assets }\end{array}$ & $\begin{array}{l}\text { - Innovation and appropriate cost-effective } \\
\text { technology } \\
\text { - Technology advancements with significant } \\
\text { environmental impacts }\end{array}$ \\
\hline & & $\begin{array}{l}\text { Resource } \\
\text { efficiency }\end{array}$ & $\begin{array}{l}\text { Technological know-how: } \\
\text { - Labour efficiency - demand integration of } \\
\text { knowledge from different disciplines }\end{array}$ \\
\hline & $\begin{array}{l}\text { Reducing } \\
\text { commodity } \\
\text { price volatility }\end{array}$ & $\begin{array}{l}\text { Trends in food } \\
\text { consumption }\end{array}$ & $\begin{array}{l}\text { Cost: } \\
\text { The way food is produced }\end{array}$ \\
\hline
\end{tabular}

improving land and water management; effectively using technology; reducing trading price; and, sustainable sourcing. To enhance the nutritious food involved in selecting diet component ingredient (for improving animal health and productivity), local feed resources or natural resources can be used. Reducing trading price emphasises the involvement of the authorities. To improve land and water management, the technology in waste products to produce feed for livestock is highlighted. The sustainable sourcing explains the authorities' involvement in policy implementation (feed control).

In animal health, G\&S criteria is discovered in enhancing nutrition; sustainable sourcing and improving land and water management. Enhancing nutrition comes with the use of natural resources as an alternative to drugs. Sustainable sourcing is described as the government's involvement in regulations in limiting the use of drugs on animals. In terms of improving land and water management, training is required for animal welfare in implementing good husbandry, a better environment and hygiene, rather than use the drugs.
The G\&S criteria identify housing activities in the effective use of technology, enhancing nutrition and improving land and water management. Effectively using technology is explained as using technological innovation to improve livestock production and resource efficiency (better breeding, light energy efficiency); enhance nutrition in natural resources by using local resources and ensuring healthy diet and animal welfare and socialcultural benefits (affordable price and healthy food); improving land and water management in health and house management (odour, noise, waste); and, ensuring goodhealth and building layout (space, ventilation, light, weather).

After housing activities, the poultry goes through animal product activities. In animal product activities, the G\&S criteria are effectively used technology through technological advancement that focuses on extending shelf life, improvement of sensory properties and digestibility and enhancement of the health effects of food.

Then, in animal transport activities, the G\&S criteria are improving land and water management. The animal transport activities 
involve expert knowledge and expert workers to overcome stress during handling animal (animal welfare). Education and training are required in transportation activities so that it improves land management.

For slaughterhouse activities, it contains three steps: i) pre-slaughter handling activities, ii) during the slaughtering process and iii) after the slaughtering process. For each of the stages, the G\&S criteria si described as improving land and water management and technological advancement (energy consumption). Improving land and water management involves workers' knowledge and skills in maintaining the slaughtering house activities. It includes animal treatment, cleaning, hygiene procedures. In terms of technological advancements, the G\&S criteria involves the waste treatment after the slaughtering process.

The last activities in the first stage are distribution and storage activity, which focuses on temperature, the meat chill chain and transportation. This activity involves G\&S criteria in the efficient use of technology, an example of product hygiene and product handling.

The second stage of poultry production and management process is food processing. The G\&S criteria discuss the effective use of technology (equipment efficiency); health and house management (transportation and handling system); and, improving water management (water waste, effluent, air and waste).

The third stage of poultry production and management process is the retailer. The first aspect of G\&S criteria in this activity is the effective use of technology, which emphasises technological efficiency (temperature control and packaging).

The final stage of poultry production and management process is the consumer. The G\&S criteria in consumer activities are the effective use of technology, which focuses on technological efficiency in labelling. Table 2 clarifies the G\&S criteria in poultry production and management process.

Table 2: Green and sustainability criteria in poultry production and management

\begin{tabular}{|c|c|c|}
\hline $\begin{array}{l}\text { Primary } \\
\text { Production }\end{array}$ & Based on 5 Pillars & G\&S Criteria \\
\hline \multirow[t]{2}{*}{$\begin{array}{l}\text { STAGE 1: } \\
\text { Breeding }\end{array}$} & $\begin{array}{l}\text { Improving land and } \\
\text { water management }\end{array}$ & \multirow[t]{2}{*}{$\begin{array}{l}\text { Animal welfare, technology innovation and health and house } \\
\text { management }\end{array}$} \\
\hline & $\begin{array}{l}\text { Effective use of } \\
\text { technology }\end{array}$ & \\
\hline \multirow[t]{6}{*}{ Feeding } & Enhancing nutrition & $\begin{array}{l}\text { - Selecting diet component ingredients to improve animal } \\
\text { health and productivity }\end{array}$ \\
\hline & & - Using local feed resources or natural resources; \\
\hline & $\begin{array}{l}\text { Improving land and } \\
\text { water management }\end{array}$ & $\begin{array}{l}\text { Improving land and water management and technology in waste } \\
\text { products that can be used to produce feed for livestock }\end{array}$ \\
\hline & $\begin{array}{l}\text { Effective use of } \\
\text { technology }\end{array}$ & \\
\hline & Reducing trading price & $\begin{array}{l}\text { Reducing trading price through the involvement of the } \\
\text { authorities }\end{array}$ \\
\hline & Sustainable sourcing & $\begin{array}{l}\text { Sustainable sourcing is described as the authorities'involvement } \\
\text { in policy implementation (feed control). }\end{array}$ \\
\hline
\end{tabular}




\begin{tabular}{|c|c|c|}
\hline \multirow[t]{3}{*}{ Animal health } & Enhancing nutrition & The use of natural resources as an alternative for drugs \\
\hline & Sustainable sourcing & $\begin{array}{l}\text { Sustainable sourcing describes the government's involvement in } \\
\text { regulations for limiting the use of drugs on animals }\end{array}$ \\
\hline & $\begin{array}{l}\text { Improving land and } \\
\text { water management. }\end{array}$ & $\begin{array}{l}\text { Training is needed for animal welfare in implementing good } \\
\text { husbandry, good environment and hygiene, rather than use the } \\
\text { drugs. }\end{array}$ \\
\hline \multirow[t]{3}{*}{ Housing } & $\begin{array}{l}\text { Effective use of } \\
\text { technology }\end{array}$ & $\begin{array}{l}\text { Technological innovation in improving livestock production and } \\
\text { resource efficiency (better breeding, light energy efficiency) }\end{array}$ \\
\hline & Enhancing nutrition & $\begin{array}{l}\text { Utilising natural resources by using local resources and healthy } \\
\text { diet and animal welfare and social-cultural benefits (affordable } \\
\text { price and healthy food) }\end{array}$ \\
\hline & $\begin{array}{l}\text { Improving land and } \\
\text { water management }\end{array}$ & $\begin{array}{l}\text { Health and house management (odour, noise, waste); health and } \\
\text { building layout (space, ventilation, light, weather) }\end{array}$ \\
\hline Animal product & $\begin{array}{l}\text { Effective use of } \\
\text { technology }\end{array}$ & $\begin{array}{l}\text { Technological advancements focusing on extending shelf } \\
\text { life, improvement of sensory properties and digestibility and } \\
\text { enhancement of health effects of food. }\end{array}$ \\
\hline $\begin{array}{l}\text { Animal } \\
\text { transport }\end{array}$ & $\begin{array}{l}\text { Improving land and } \\
\text { water management }\end{array}$ & $\begin{array}{l}\text { Involving expert knowledge and expert workers as needed to } \\
\text { overcome stress during handling of animals (animal welfare). } \\
\text { Education and training are needed in transportation activities so } \\
\text { that land management can be improved. }\end{array}$ \\
\hline \multirow[t]{3}{*}{ Slaughterhouse } & $\begin{array}{l}\text { Improving land and } \\
\text { water management }\end{array}$ & $\begin{array}{l}\text { Workers' knowledge and skills in maintaining the slaughtering } \\
\text { house activities. It includes animal treatment, cleaning, hygiene } \\
\text { procedures. }\end{array}$ \\
\hline & $\begin{array}{l}\text { Effective use of } \\
\text { technology }\end{array}$ & Technological advancements (energy consumption): \\
\hline & & Waste treatment after the slaughtering process. \\
\hline $\begin{array}{l}\text { Distribution } \\
\text { and storage } \\
\text { activities }\end{array}$ & $\begin{array}{l}\text { Effective use of } \\
\text { technology }\end{array}$ & $\begin{array}{l}\text { Technological efficiency - product hygiene and product } \\
\text { handling. }\end{array}$ \\
\hline $\begin{array}{l}\text { STAGE 2: } \\
\text { Food } \\
\text { processing }\end{array}$ & $\begin{array}{l}\text { Effective use of } \\
\text { technology }\end{array}$ & $\begin{array}{l}\text { Technological efficiency (equipment efficiency); health and } \\
\text { house management (transportation and handling system); and, } \\
\text { improving water management (water waste, effluent, air and } \\
\text { waste). }\end{array}$ \\
\hline $\begin{array}{l}\text { STAGE 3: } \\
\text { Retailers }\end{array}$ & $\begin{array}{l}\text { Effective use of } \\
\text { technology }\end{array}$ & Technological efficiency (temperature control and packaging). \\
\hline $\begin{array}{l}\text { STAGE 4: } \\
\text { Consumer }\end{array}$ & $\begin{array}{l}\text { Effective use of } \\
\text { technology }\end{array}$ & Technological efficiency in labelling. \\
\hline
\end{tabular}

\section{Materials and Methods}

This study focused on knowledge of the G\&S criteria in the poultry production management process. This study uses a qualitative approach by interviewing a sample of top management figures in the management and operation production unit from one halal broiler company in Malaysia and government agencies. The questionnaire is developed based on semistructured interviews that focused on indepth information on the development of 
knowledge on the G\&S criteria of the poultry production, the knowledge justification on the application of G\&S and how researchers come to know what they know. In this context, the study is to understand the respondent perspective on "how G\&S criteria are being practised", "what are the benefits of the implementation of $G \& S$ in poultry production and management"; and "what_G\&S could offer to poultry production and management". Based on Saunders et al. (2012), qualitative research examines participants' meanings and the relationships between them to develop a conceptual framework. The purpose here would be to gain an understanding on how they implement it to understand better the nature of the problem.

\section{Sampling Technique}

The purposive sampling technique is used in this study. According to Patton (2002), purposive sampling is used to select "information-rich" cases. This study interviews 30 respondents and uses heterogeneous purposive sampling (maximum variation sampling) that the respondents selected according to their knowledge, expertise and experience in their division. The number of interviewees is sufficient as it helps enrich the data collection, as suggested by Saunders et al. (2012), who stated that heterogeneous purposive sampling should have samples sizes of between 12 and 30 . Based on Yin (2014), data collection procedures include the names of contact persons doing the fieldwork, data collection plans (covering the type of evidence to be expected, including the roles of people to be interviewed, the events to be observed, and any other documents to be review when on-site) and expected preparation before fieldwork (includes identifying specific information to be reviewed and issues to be covered before fieldwork). Table 3 lists the position level of each organisation involved.

In this study, the researchers interviewed respondents from the halal broiler company's five departments: breeder division, broiler division, processing plant, feed mill division and administration. The respondents from the company hold the positions of senior manager and manager. Other respondents are from government agencies, namely JAKIM, HDC,

Table 3: The Respondent Position Level in the Organisation

\begin{tabular}{lll}
\hline $\begin{array}{l}\text { Name of contact } \\
\text { person (refer to } \\
\text { Table 4.1) }\end{array}$ & \multicolumn{1}{c}{$\begin{array}{c}\text { Respondent (R) 1-10 from Halal Broiler } \\
\text { Company }\end{array}$} & $\begin{array}{l}\text { R11-R30 from JAKIM, HDC, } \\
\text { DOE, STANDARD, MoA, SIRIM, } \\
\text { MARDI, MoH and MATRADE }\end{array}$ \\
\hline $\begin{array}{l}\text { Data collection } \\
\text { plans }\end{array}$ & Interview and observation & Interview \\
\hline Roles & Upper level position (senior manager) & $\begin{array}{l}\text { Upper level position (senior } \\
\text { manager) }\end{array}$ \\
\hline $\begin{array}{l}\text { Events to be } \\
\text { observed }\end{array}$ & Plantation farm and processing plantation & $\begin{array}{l}\text { Management procedure on the } \\
\text { current G\&S practices for food and } \\
\text { producers }\end{array}$ \\
\hline $\begin{array}{l}\text { Documentation } \\
\text { as evidence }\end{array}$ & Halal food certificate and any G\&S certificate & $\begin{array}{l}\text { Any G\&S policy or regulations for } \\
\text { food producers }\end{array}$ \\
\hline $\begin{array}{l}\text { Expected } \\
\text { preparation prior } \\
\text { to the fieldwork }\end{array}$ & $\begin{array}{l}\text { To know the poultry production division: the } \\
\text { operation of each division (farming plantation- } \\
\text { breeder, broiler, hatching) and processing } \\
\text { division (slaughtering), retailing and consumer } \\
\text { (QSR Brands) }\end{array}$ & $\begin{array}{l}\text { To know the roles of the } \\
\text { organisation }\end{array}$ \\
\hline $\begin{array}{l}\text { Issues to be } \\
\text { covered }\end{array}$ & $\begin{array}{l}\text { Any G\&S practices in the poultry production } \\
\text { process }\end{array}$ & $\begin{array}{l}\text { Any regulations or current G\&S } \\
\text { practices in the entire poultry } \\
\text { production and management process }\end{array}$ \\
\hline
\end{tabular}


DOE, STANDARD, MOA, SIRIM, MARDI, the Ministry of Health and MATRADE, and they hold the positions of director and deputy director.

A respondent from JAKIM is an assistant manager at the agency's halal hub division, which is involved operating procedures, including being in charge of companies. Generally, JAKIM is involved in the slaughtering process and it requires companies to follow the halal procedure. The slaughtering process happens durirng food processing, which is under the processing plant division. Thus, there is relevance in interviewing them to gain in-depth information on the operation of halal inspection in Malaysia and outside Malaysia.

The Global Halal SupportCentre(GHSC) is a HDC division, which delivers information about the current halal market in Malaysia. HDC is part of an agency under the Ministry of International Trade and Industries, which coordinates the development of the halal industry in Malaysia, especially in terms of halal standards, audit and certification, capacity building for halal products and services, and promotes participation and facilities growth of Malaysian companies in the global halal market. Respondents' hold the positions of senior manager, assistant manager and executive manager. GHSC serves as a platform for companies, investors, or even researchers to gather information related to halal principles, industry statistics, market trends and certification compliance. The relevance of interviewing personnel in this division is that the respondents are attached to the newly established halal companies or investors through programmes and seminars and one-toone business consultancies. The respondents answered questions that are relevant to how to adopt G\&S into halal companies and exporters so that they could reach the global market. The research questions are more about what services do HDC offer and the potential of the halal companies in implementing it.

The Department of Environment (DOE) is under the Ministry of Natural Resources and Environment. DOE plays a role in preventing, eliminating and controlling pollution, as well as improving the environment, including air, water, and monitoring hazardous waste from processing poultry plantation. DOE officers were interviewed to investigate the department's participation in G\&S practices, particularly in poultry production and management.

The Department of Standards Malaysia (STANDARDS Malaysia) is under the Ministry of Science, Technology and Innovation (MOSTI). Standards Malaysia is the National Standards Body and National Accreditation Body. The four respondents from this department are from the accreditation unit, which is directly involves constructing the standards for industries.

Five respondents from the Ministry of Agriculture (MOA), is from the Crop, Livestock and Fishery Industries Division and the Agrobased Industry Division. The respondents from this division hold positions in the branch plant, and they are attached closely to the agricultural mission in the Economic Transformation Programme (ETP). They were interviewed for this study to gain information on the latest update from the Ministry of Agriculture and Agro-based Industry Malaysia on G\&S practices in Malaysia. Documentation or data from its official portal was not sufficient to gain in-depth information.

The Malaysia External Trade Development Corporation (MATRADE) was established to promote, assist and develop Malaysia's external trade with a particular emphasis on the export of manufactured and semi-manufactured products and on selective basis import, as well as to formulate and implement a national export marketing strategy, and enhance and protect Malaysia's international trade interests abroad. Two officers from MATRADE were interviewed to gain information on how G\&S could assist the poultry industry in Malaysia in penetrating the global market.

SIRIM is the premier industrial research and technology organisation in Malaysia, and it is an agency under the Ministry of Science, Technology and Innovation (MOSTI). A SIRIM officer was interviewed for this study 
to gain knowledge on the agency's role and contributions to the food industry, especially in terms of G\&S practices. In this context, SIRIM has the unique advantages of research and technology innovation, industry standards and quality.

MARDI was established to generate and promote new, appropriate and efficient technologies in for food advancement, agriculture, food and agro-based industries. For the livestock industry, particularly in poultry, research is being done to develop local raw materials, especially in reducing the import of feed ingredients. In this study, a MARDI officer was interviewed to identify recent researches using local sources (resource efficiency) in broiler processes, and any recent research on poultry sustainability (more on environment preservation) and any programme organised by MARDI to facilitate agropreneur in implementing resource efficiency.

The Food Safety and Quality Division (FSQD) is under the Ministry of Health $(\mathrm{MoH})$, which is responsible for protecting the public against health hazards and fraud in the preparation, sale and use of food. It includes food safety guidelines; import and export food regulations; health food certification; and, food law, including the Bersih, Selamat dan
Sihat (BESS) guideline, Makanan Selamat Tanggungjawab Industri (MeSTI) guideline, HACCP guideline and GMP guideline. The two staff members from FSQD were interviewed to investigate any G\&S practices written in any guideline published by FSQD.

These respondents are significant for the study since one of the respondents is attached closely to halal production and holds a high management in his division, and both respondents' views and opinions were strongly supported by their positions and experience. Consequently, this gave the primary data collected higher validity and reliability. The researchers selected the respondents through the organisational chart and made phone calls to the organisations. Requests for interviews are done via email and telephone conversations, and formal letters on the interview sessions for the research were sent.

\section{Analysing Data}

This study interprets the data by identifying the theme and understanding the patterns according to the content analysis as shown in Table 4 . Patton (2002) states that in content analysis, the pattern and themes appear in expressive results in which the sentence brings the same meaning in terms of theme and content.

Table 4: Content categories, themes and pattern based on literature

\begin{tabular}{|c|c|c|c|}
\hline $\begin{array}{c}\text { Food } \\
\text { Production } \\
\text { Process }\end{array}$ & Content Categories & Themes & Pattern \\
\hline \multirow[t]{5}{*}{ Breeding } & \multirow{2}{*}{$\begin{array}{l}\text { Improving land and } \\
\text { water management }\end{array}$} & \multirow{2}{*}{$\begin{array}{l}\text { Education and training to } \\
\text { gain necessary skills }\end{array}$} & - Animal welfare \\
\hline & & & - Health and house management \\
\hline & \multirow{3}{*}{$\begin{array}{l}\text { Effective use of } \\
\text { technology }\end{array}$} & \multirow{2}{*}{$\begin{array}{l}\text { Improving productive } \\
\text { assets }\end{array}$} & - Technology innovation \\
\hline & & & - Health and house management \\
\hline & & \multicolumn{2}{|l|}{ Resource efficiency } \\
\hline \multirow[t]{4}{*}{ Feeding } & $\begin{array}{l}\text { Improving land and } \\
\text { water management }\end{array}$ & $\begin{array}{l}\text { Education and training to } \\
\text { gain necessary skills }\end{array}$ & - Improve waste products \\
\hline & \multirow[t]{2}{*}{$\begin{array}{l}\text { Effective use of } \\
\text { technology }\end{array}$} & $\begin{array}{l}\text { Improving productive } \\
\text { assets }\end{array}$ & - Improve waste products \\
\hline & & \multicolumn{2}{|l|}{ Resource efficiency } \\
\hline & $\begin{array}{l}\text { Reducing trading } \\
\text { price }\end{array}$ & $\begin{array}{l}\text { Trends in food } \\
\text { consumption }\end{array}$ & - Cost - authority involvement \\
\hline
\end{tabular}




\begin{tabular}{|c|c|c|c|}
\hline & \multirow[t]{2}{*}{ Sustainable sourcing } & \multicolumn{2}{|l|}{$\begin{array}{l}\text { Integration of } \\
\text { selecting supplier }\end{array}$} \\
\hline & & $\begin{array}{l}\text { Relationship } \\
\text { with supplier by } \\
\text { developing policy }\end{array}$ & $\begin{array}{l}\text { - Policy implementation (feed } \\
\text { control) -authority involvement }\end{array}$ \\
\hline & Enhancing nutrition & $\begin{array}{l}\text { Providing affordable and } \\
\text { nutritious food products }\end{array}$ & $\begin{array}{l}\text { - Selecting diet component } \\
\text { ingredients } \\
\text { - Use local feed resources or natural } \\
\text { resources }\end{array}$ \\
\hline \multirow[t]{4}{*}{ Animal Health } & $\begin{array}{l}\text { Improving land and } \\
\text { water management }\end{array}$ & $\begin{array}{l}\text { Education and training to } \\
\text { gain necessary skills }\end{array}$ & $\begin{array}{l}\text { Animal welfare -training is } \\
\text { needed to reduce disease in farms }\end{array}$ \\
\hline & & $\begin{array}{l}\text { Integration of } \\
\text { selecting supplier }\end{array}$ & \\
\hline & Sustainable sourcing & $\begin{array}{l}\text { Relationship } \\
\text { with supplier by } \\
\text { developing policy }\end{array}$ & $\begin{array}{l}\text { - Government and regulations (limit } \\
\text { use veterinary drugs) }\end{array}$ \\
\hline & Enhancing nutrition & $\begin{array}{l}\text { Providing affordable and } \\
\text { nutritious food products }\end{array}$ & $\begin{array}{l}\text { - Natural alternatives (drug use) } \\
\text { - Animal welfare }\end{array}$ \\
\hline \multirow[t]{5}{*}{ Housing } & $\begin{array}{l}\text { Effective use of } \\
\text { technology }\end{array}$ & $\begin{array}{l}\text { Improving productive } \\
\text { assets }\end{array}$ & $\begin{array}{l}\text { - Technology innovation (to } \\
\text { improve livestock production) }\end{array}$ \\
\hline & & Resource efficiency & $\begin{array}{l}\text { - Technological know-how, labour } \\
\text { efficiency (better breeding, light } \\
\text { energy efficiency) }\end{array}$ \\
\hline & Enhancing nutrition & $\begin{array}{l}\text { Providing affordable and } \\
\text { nutritious food products }\end{array}$ & $\begin{array}{l}\text { - Natural resources (local resources } \\
\text { and healthy diet) }\end{array}$ \\
\hline & & & $\begin{array}{l}\text { - Animal welfare and social cultural } \\
\text { benefits (affordable price and } \\
\text { healthy food) }\end{array}$ \\
\hline & $\begin{array}{l}\text { Improving land and } \\
\text { water management }\end{array}$ & $\begin{array}{l}\text { Education and training to } \\
\text { gain necessary skills }\end{array}$ & $\begin{array}{l}\text { - Health and house management } \\
\text { (odour, noise, waste); health and } \\
\text { building layout (space, ventilation, } \\
\text { light, weather) }\end{array}$ \\
\hline \multirow[t]{2}{*}{$\begin{array}{l}\text { Animal } \\
\text { Products }\end{array}$} & $\begin{array}{l}\text { Effective use of } \\
\text { technology }\end{array}$ & $\begin{array}{l}\text { Improving productive } \\
\text { assets }\end{array}$ & $\begin{array}{l}\text { Technological advancement } \\
\text { (preservation to extend shelf } \\
\text { life, improvement of sensory } \\
\text { properties and digestibility and } \\
\text { enhancement of the health effects } \\
\text { of food) }\end{array}$ \\
\hline & & Resource efficiency & \\
\hline $\begin{array}{l}\text { Animal } \\
\text { Transport }\end{array}$ & $\begin{array}{l}\text { Improving land and } \\
\text { water management }\end{array}$ & $\begin{array}{l}\text { Education and training to } \\
\text { gain necessary skills }\end{array}$ & - Health and house management - \\
\hline
\end{tabular}




\begin{tabular}{|c|c|c|c|}
\hline \multirow[t]{3}{*}{ Slaughterhouse } & $\begin{array}{l}\text { Improving land and } \\
\text { water management }\end{array}$ & $\begin{array}{l}\text { Education and training to } \\
\text { gain necessary skills }\end{array}$ & $\begin{array}{l}\text { Health and house management } \\
\text { - workers knowledge and skills } \\
\text { on maintaining the slaughtering } \\
\text { house activities. includes animal } \\
\text { treatment, cleaning, hygiene } \\
\text { procedures }\end{array}$ \\
\hline & \multirow[t]{2}{*}{$\begin{array}{l}\text { Effective use of } \\
\text { technology }\end{array}$} & $\begin{array}{l}\text { Improving productive } \\
\text { assets }\end{array}$ & $\begin{array}{l}\text { Technology advancement -energy } \\
\text { consumption (waste treatment } \\
\text { after slaughtering) }\end{array}$ \\
\hline & & Resource efficiency & \\
\hline \multirow[t]{2}{*}{$\begin{array}{l}\text { Distribution } \\
\text { and storage }\end{array}$} & \multirow[t]{2}{*}{$\begin{array}{l}\text { Effective use of } \\
\text { technology }\end{array}$} & $\begin{array}{l}\text { Improving productive } \\
\text { assets }\end{array}$ & $\begin{array}{l}\text { - Product hygiene and product } \\
\text { handling }\end{array}$ \\
\hline & & Resource efficiency & \\
\hline \multirow[t]{2}{*}{$\begin{array}{l}\text { Food } \\
\text { Processing }\end{array}$} & \multirow[t]{2}{*}{$\begin{array}{l}\text { Effectively using } \\
\text { technology }\end{array}$} & $\begin{array}{l}\text { Improving productive } \\
\text { assets }\end{array}$ & $\begin{array}{l}\text { - Hygiene in equipment } \\
\text { - Improving water management } \\
\text { (water waste, effluent, air and } \\
\text { waste) }\end{array}$ \\
\hline & & Resource efficiency & $\begin{array}{l}\text { - Technological know-how } \\
\text { - Labour efficiency- health and } \\
\text { house management (transportation } \\
\text { and handling system) }\end{array}$ \\
\hline \multirow{2}{*}{$\begin{array}{l}\text { Retail } \\
\text { (Distribution } \\
\text { and storage) }\end{array}$} & \multirow[t]{2}{*}{$\begin{array}{l}\text { Effective use of } \\
\text { technology }\end{array}$} & $\begin{array}{l}\text { Improving productive } \\
\text { assets }\end{array}$ & $\begin{array}{l}\text { - Temperature control and } \\
\text { packaging }\end{array}$ \\
\hline & & Resource efficiency & \\
\hline \multirow[t]{2}{*}{$\begin{array}{l}\text { Consumer } \\
\text { (Distribution } \\
\text { and storage) }\end{array}$} & \multirow[t]{2}{*}{$\begin{array}{l}\text { Effective use of } \\
\text { technology }\end{array}$} & $\begin{array}{l}\text { Improving productive } \\
\text { assets }\end{array}$ & - Labelling \\
\hline & & Resource efficiency & \\
\hline
\end{tabular}

Data are analysed based on three pillars: the environmental, social and economic sectors. The key pattern is based on the words related to the themes. For example, responses of "to get sources from the local supplier" or "we are researching by using local resources".

\section{Results and Discussion}

The results gathered from this study are presented in two forms: i) poultry production development in Malaysia and ii) G\&S criteria in Malaysia poultry production and management.

First, the data gathered to explain poultry production development and progress in Malaysia is obtained from official government agency documentation (refer to National
Agriculture Policy (1984-2010) and National Agrofood Policy (2011-2020). The data shows the evolution of poultry production in Malaysia. There are three phases in the National Agriculture Policy: Phase 1: 1984 -1991; Phase 2:1992-2010 and Phase 3:1998-2010, and there is no information about poultry industries on Phases 1 and 3. The Malaysian government then introduced the National Agro-Food Policy (NAFP) for the years 2011 to 2020 (Abu Dardak, 2015).

During the Third National Agricultural Policy (NAP) in 1998-2010, Malaysia moved towards the implementation of G\&S activities in the agricultural sector by introducing a new approach to increase productivity and competitiveness and utilised natural resources 
on a sustainable basis (Ministry of Agriculture, 2010). In general, the Third NAP strategies explained the G\&S development by optimising the use of resources, accelerating agro-based industrial development, enhaning research and development efforts and technological diffusion, having a greater role of the private sector, reforming marketing strategies, expanding food production, developing human resources, and viable and self-reliant farmers and fishermen institutions and restructuring management capacity to include greater Bumiputera participation. However, when the researchers investigated, one of the strategies for the poultry industry is to ensure that there is sufficient egg and poultry supply. When NAFP was introduced for the time period of 2011-2020, the policy briefly highlights sustainable food production strategies in nutritional aspects, including agricultural land, development and infrastructure by expanding the compliance of standards. The NAFP is focused on strengthening human capital and skilled labour force, especially for modern technology and mechanisation to reduce the dependency of manpower in the agricultural sector. According to Nazmi et al.(2015), poultry production (particularly in the broiler industry) sustained as a competitive industry by encouraging modern technology in a closed house system, and the automation and use of effective microorganisms as natural control agents. Furthermore, the government also provides sector-based incentives to encourage the private sector to invest in agriculture and agro-based industry (Abu Dardak, 2015).

The progress of the poultry production in Malaysia continued with the evolution of the MyGAP (Malaysian Good Agricultural Practices) guideline in 2013, the Animal Welfare Act in 2015 and JAKIM's participation with the halal establishment of food production. The setting up of the Federation of Livestock Farmers' Associations of Malaysia (FLFAM) has also safeguarded welfare and the advancement of technology know-hows in the Malaysian poultry industries.

In terms of the MyGAP guideline development, according to an officer from the
Agriculture Division from MOA, agriculture in Malaysia needs to update according to the current demand. T officer states that "MyGAP guideline is a rebranding programme that we announce to replace three certificates: Malaysian Farm Certification Scheme for Good Agricultural Practices (SALM), Livestock Farm Practices Scheme (SALT) and Malaysian Aquaculture Farm Certification Scheme (SPLAM). This is because we are now want to upgrade our scheme to be more acceptance and encourage our farmers or food producer to apply this scheme. We don't want people out there are confused with the different logo before this. So, now food producer, no matter they are from livestock, crops or aqua will only use one logo, which is MyGAP guideline." Furthermore, according to Cheng (2016) as good agricultural practices are being accepted worldwide, the establishment of the MyGAP guideline would encourage food producers to practise modern farming to achieve better performance and make Malaysia livestock products competititve in the global market. Rabu et al. (2016) stated that the MyGAP guideline scheme was developed with the cooperation of STANDARD Malaysia, which strengthened the scheme's reliability. For livestock practices (including poultry), the MyGAP guideline is constructed based on the Malaysian Standard (MS) - MS2027:2006 Good Animal Husbandry Practice (GAHP). The guideline focuses on herd health programmes; bio-security programmes; premise and infrastructure; use of medication; waste management and pollution control and animal welfare, which lead to environmental pollution control, guaranteed safer product produce and better health and contribute to the disease-free status. An officer from the Agriculture Division, MOA mentions that "once when the producer has applied MyGAP guideline, we will visit their farm based on the guideline given. Then, for the water waste, the effluent should dispose in the right way; and their workers must take an injection. We will monitor their farm and before 6 months their certificate is due, they will remind to renew. The benefits of applying MyGAP guideline has increased their productivity, quality and 
preserving the environment." Furthermore, the good thing about this certification is that no payment is needed to impose th eMyGAP guideline certification. According to an assistant secretary from MOA, "the MyGAP guideline is free. No payment needed. But it needs to be renewed every two years."

In other aspects, the MyGAP guideline is driven by the ASEAN Good Animal Husbandry Practices (ASEAN GAHP) negotiations in strengthening poultry production and management in Malaysia. Malaysia participated in forming the ASEAN GAHP to set up food safety, animal welfare and environmental sustainability modules for poultry. The importance of ASEAN GAHP in this study is to show Malaysia's involvement in developing formality in moving towards new poultry production and management advancements in G\&S practices. However, there are activities in poultry production and management that are not in the MyGAP guideline, but have been reviewed at the ASEAN GAHP level. Besides, ASEAN members share common farming practices, infrastructures and weather patterns. The assistant secretary from MOA added that "the MyGAP guideline potentially harmonises ASEAN GAHP regulations, especially in export matters".

The Animal Welfare Act 2015 is constructed based on Malaysia Standard (MS) 2027:2006 Good Animal Husbandry Practice (GAHP) and Malaysian Standards MS 1500:2009 Halal production, handling and storage (Nizamuddin, 2014). The parts of the Animal Welfare Act 2015 in Malaysia that relates to poultry production and management are the transportation of animals and slaughtering of animals. In Europe, animal welfare has been established through legislation in terms of animal housing, feed and care (animal disease prevention and treatment) and it is recommended that animal welfare should be science-based, reliable and repeatable, feasible and practical. The difference between the Animal Welfare Act 2015 and animal welfare in Europe is that European regulations are more comprehensive. Thus, this section explains how far poultry production and management could be implemented in Malaysia.

JAKIM's participation in halal regulations in poultry production and management is based on MS 1500:2009 Halal - production, preparation, handling and storage-general guidelines (second revision) in producing quality halal products. In developing halal regulations, the collaboration between JAKIM, DVS, STANDARD, Ministry of Health Malaysia, MITI and SIRIM agencies had strengthened the halal regulations guideline. In this guideline, MS 1500:2009 focuses on abattoir, poultry processing plant on slaughtering, stunning method, dressing process, storage, transportation of halal poultry and their products. Furthermore, the halal process is part of green procedures. Mohamed Yunos et al. (2014) stated that by understanding halal principles and practices, one may realise that the halal concept is also related to green concepts. The halal certification focuses on the hygienic, quality, and safety aspects of the food and its preparation; while green management focuses on reducing the negative impact of human activities towards the environment. As in the results shown in Table 5, poultry development in Malaysia is conducted through the regulations imposed by the government to strengthen the poultry industry. 
Table 5: Poultry Production Development in Malaysia

\begin{tabular}{|c|c|}
\hline $\begin{array}{l}\text { Ministry/Institution/ } \\
\text { Guideline }\end{array}$ & Scope guideline \\
\hline Animals Act 1953 & $\begin{array}{l}\text { - Importation and exportation of animals and birds } \\
\text { - Prevention of the spread of disease } \\
\text { - Conservation of livestock } \\
\text { - Improvement of livestock (for bulls) }\end{array}$ \\
\hline $\begin{array}{l}\text { MYGAP Livestock } \\
\text { Guideline } 2014\end{array}$ & $\begin{array}{l}\text { - Health programme } \\
\text { - Bio-security programme } \\
\text { - Premise and infrastructure } \\
\text { - Use of medication } \\
\text { - Waste management and pollution control } \\
\text { - Animal welfare }\end{array}$ \\
\hline Animal Welfare Act 2015 & $\begin{array}{l}\text { - Transportation } \\
\text { - Animal in distress }\end{array}$ \\
\hline $\begin{array}{l}\text { Malaysia Standard Good } \\
\text { Animal Husbandry Practice }\end{array}$ & - Skill and responsibilities of producers and workers \\
\hline MS 2027:2006 & $\begin{array}{l}\text { - Legal responsibilities } \\
\text { - Cruelty and neglect } \\
\text { - Feeds and feeding } \\
\text { - Breeding and reproduction } \\
\text { - Weaning } \\
\text { - Farm bio-security } \\
\text { - Farm sanitisation programme } \\
\text { - Animal health management } \\
\text { - Farm and animal management record } \\
\text { - Farm design, infrastructure, facilities and equipment/management tools } \\
\text { - Handling and restraining of animals } \\
\text { - Transportation } \\
\text { - Environmental management }\end{array}$ \\
\hline
\end{tabular}

The G\&S criteria in Malaysia's poultry production and management are highlighted in Table 6. Table 6 shows that there are four content categories highlighted in these studies: i) effective use of technology; ii) enhancing nutrition; iii) sustainable sourcing; and, iv) improving land and water management.

First, the effective use of technology are in breeding activities (technological advancement in genetic selection), animal products activities (packaging design in technological advancement), distribution and storage activities (cold storage requirement for the meat chill chain and transportation), food processing activities (equipment design and waste management to improve productive assets and appointing
Muslim officers in resource efficiency), retail activities (temperature control and packaging) and consumer activities (smart labelling technology). Second, in terms of enhancing nutrition content categories, Malaysia focuses on feed and animal health activities (both for animal diet) as stated in the legislation. Third, for the sustainable sourcing content category, Malaysia is stated in animal feeding activity through food consumption trend for the halal requirement. It is important to have a relationship with suppliers to develop policies in terms of halal requirement. Fourth, for improving land and water management content categories, it looks into animal health activities (animal health program), housing activities (health and 
house management as addressed in legislation document), animal transport activities (animal welfare in terms of workers education and skills) and slaughterhouse activities as stated in MS1500:2009 regulations.

The results also showed that Malaysia's progress towards G\&S practices in poultry production is moving moderately. As mentioned earlier, Shauqi et al. (2015) stated that poultry industries in Malaysia are moving towards a closed house system (with $70 \%$ poultry producer implement closed house system) and are using more modern technology to be competitive in the food industry. The roles played by the government agencies (JAKIM, HDC, DOE, STANDARD, MOA, MATRADE, SIRIM and $\mathrm{MoH}$ ) helps improve policies for poultry producers. However, until the study is done, there is no authorised documentation on G\&S practices for the poultry industry. Even though the MyGAP guideline scheme is not mandatory for poultry producers, the scheme helps in providing a better guideline to manage poultry production.

Table 6: Summary of Malaysia Results Based on Content Categories, Themes and Pattern

\begin{tabular}{|c|c|c|c|}
\hline FPFM & $\begin{array}{c}\text { Content } \\
\text { categories }\end{array}$ & Themes & Pattern \\
\hline Breeding & $\begin{array}{l}\text { Effective use of } \\
\text { technology }\end{array}$ & $\begin{array}{l}\text { Improving productive } \\
\text { assets }\end{array}$ & $\begin{array}{l}\text { Technology advancement: } \\
\text { - Improve breeding genetic with local } \\
\text { breed }\end{array}$ \\
\hline \multirow[t]{3}{*}{$\begin{array}{l}\text { Animal } \\
\text { Feeding }\end{array}$} & \multirow[t]{2}{*}{$\begin{array}{l}\text { Enhancing } \\
\text { nutrition }\end{array}$} & \multirow[t]{2}{*}{$\begin{array}{l}\text { Providing affordable and } \\
\text { nutritious food products }\end{array}$} & $\begin{array}{l}\text { Animal diet: } \\
\text { - Legislation:MS20:2008, MS2027:2006 } \\
\text { in GAHP and Guidelines for GMP for } \\
\text { Feed (2014) }\end{array}$ \\
\hline & & & $\begin{array}{l}\text { Use natural sources: } \\
\text { - Capability of local resources could } \\
\text { enhance nutrition }\end{array}$ \\
\hline & $\begin{array}{l}\text { Sustainable } \\
\text { sourcing }\end{array}$ & $\begin{array}{l}\text { Relationship with } \\
\text { suppliers by developing } \\
\text { policy }\end{array}$ & $\begin{array}{l}\text { Policy implementation: } \\
\text { - Food consumption trends - halal } \\
\text { requirement }\end{array}$ \\
\hline \multirow[t]{2}{*}{ Animal Health } & $\begin{array}{l}\text { Improve land } \\
\text { and water } \\
\text { management. }\end{array}$ & $\begin{array}{l}\text { Education and training } \\
\text { to gain necessary skills }\end{array}$ & $\begin{array}{l}\text { Animal health program: } \\
\text { - Animal disease observation and } \\
\text { eradication programme } \\
\text { - Use medicine and vaccines correctly } \\
\text { - Workers with appropriate knowledge } \\
\text { and skills }\end{array}$ \\
\hline & $\begin{array}{l}\text { Enhancing } \\
\text { Nutrition }\end{array}$ & $\begin{array}{l}\text { Providing affordable and } \\
\text { nutritious food products }\end{array}$ & $\begin{array}{l}\text { Animal diet: } \\
\text { - Drug usage for animal health }\end{array}$ \\
\hline Housing & $\begin{array}{l}\text { Improving } \\
\text { land and water } \\
\text { management }\end{array}$ & & $\begin{array}{l}\text { Health and house management: } \\
\text { - Legislation document in MyGAP } \\
\text { (2014), MS2027:2006 in GAHP and } \\
\text { Environmental Quality (Industrial } \\
\text { Effluent) Regulations, } 2009\end{array}$ \\
\hline $\begin{array}{l}\text { Animal } \\
\text { Products }\end{array}$ & $\begin{array}{l}\text { Effective use of } \\
\text { technology }\end{array}$ & $\begin{array}{l}\text { Improving productive } \\
\text { assets }\end{array}$ & $\begin{array}{l}\text { Technology advancement: } \\
\text { - Packaging design to extend shelf life }\end{array}$ \\
\hline
\end{tabular}




\begin{tabular}{|c|c|c|c|}
\hline $\begin{array}{l}\text { Animal } \\
\text { Transport }\end{array}$ & $\begin{array}{l}\text { Improving } \\
\text { land and water } \\
\text { management }\end{array}$ & $\begin{array}{l}\text { Education and training } \\
\text { to gain necessary skills }\end{array}$ & $\begin{array}{l}\text { Animal welfare: } \\
\text { - Expertise attention (transporter) } \\
\text { who knows and have experiences in } \\
\text { handling animals } \\
\text { - Legislation documentation: } \\
\text { MS2027:2006 GAHP guideline }\end{array}$ \\
\hline Slaughterhouse & $\begin{array}{l}\text { Improving } \\
\text { land and water } \\
\text { management }\end{array}$ & $\begin{array}{l}\text { Education and training } \\
\text { skills }\end{array}$ & $\begin{array}{l}\text { Animal welfare: } \\
\text { - Cleaning process, hygiene, Halal } \\
\text { procedure - MS1500:2009 }\end{array}$ \\
\hline $\begin{array}{l}\text { Distribution } \\
\text { and storage }\end{array}$ & $\begin{array}{l}\text { Effective use of } \\
\text { technology }\end{array}$ & $\begin{array}{l}\text { Improving productive } \\
\text { assets }\end{array}$ & $\begin{array}{l}\text { Technological advancement: } \\
\text { - Cold storage requirement for meat } \\
\text { chill chain and transportation-Halal } \\
\text { requirement: MS1500:2009 guideline }\end{array}$ \\
\hline \multirow[t]{3}{*}{$\begin{array}{l}\text { Food } \\
\text { processing }\end{array}$} & \multirow[t]{3}{*}{$\begin{array}{l}\text { Effective use of } \\
\text { technology }\end{array}$} & $\begin{array}{l}\text { Improving productive } \\
\text { assets }\end{array}$ & $\begin{array}{l}\text { Technological efficiency: } \\
\text { • Equipment design }\end{array}$ \\
\hline & & & $\begin{array}{l}\text { - Waste management technology } \\
\text { efficiency }\end{array}$ \\
\hline & & Resource efficiency & $\begin{array}{l}\text { Technological know-how: } \\
\text { - Appoint Muslim halal officer }\end{array}$ \\
\hline $\begin{array}{l}\text { Retail } \\
\text { (Distribution } \\
\text { and Storage) }\end{array}$ & $\begin{array}{l}\text { Effective use of } \\
\text { technology }\end{array}$ & $\begin{array}{l}\text { Improving productive } \\
\text { assets }\end{array}$ & $\begin{array}{l}\text { Technology advancement: } \\
\text { - Temperature control and packaging }\end{array}$ \\
\hline $\begin{array}{l}\text { Consumer } \\
\text { (Transportation } \\
\text { and Storage) }\end{array}$ & $\begin{array}{l}\text { Effective use of } \\
\text { technology }\end{array}$ & $\begin{array}{l}\text { Improving productive } \\
\text { assets }\end{array}$ & $\begin{array}{l}\text { Technology advancement: } \\
\text { - Pattern of smart labelling technology }\end{array}$ \\
\hline
\end{tabular}

\section{Conclusion}

As a conclusion, results show that G\&S criteria appeared in the regulation, guideline, act and production processes. There are five guidelines and regulations for poultry production and management: Animals Acts 1953, MyGAP Livestock Guideline (2014), Animal Welfare Act 2015, Malaysia Standard Good Animal Husbandry Practice and MS2027:2006. Most of the guidelines, acts and regulations are applied to all livestock and are not specific to poultry. Interests have been shown forG\&S practices in Malaysia's guidelines and regulations and are moving moderately in poultry production and management. The roles engaged by the government agencies (JAKIM, HDC, DOE, STANDARD, MOA, MATRADE, SIRIM and $\mathrm{MoH}$ ) helps improve policies for poultry producers.
In the poultry production process, results show that Malaysia focused on four content categories: i) effective use of technology, ii) enhancing nutrition, iii) sustainable sourcing and iv) improving land and water management. However, until a study has been completed, there is no authorised documentation on G\&S practices for the poultry industry. Even though the MyGAP guideline scheme is not mandatory for poultry producers, it helps provide a better guideline to manage poultry production.

Malaysia is capable of bringing G\&S to the global market as G\&S is not only limited to how we want to produce more poultry for the future, but to identify how to use the available resources efficiently besides preserving the environment, social and economic aspects. With the alliance of the Halal Industry Development Centre (HDC), STANDARD Malaysia and JAKIM perhaps will facilitate the contribution 
of structuring the new dimension of halal green and sustainable criteria. With the discovery of this study, it will assist Malaysian industries as well as the government in adding value to the halal food industry and increase the global food market penetration.

Since Malaysia has a good reputation and is recognised worldwide as a global halal hub with the establishment of G\&S, it is easy for Malaysia to penetrate the global market. This can be seen from the demand for green and sustainability itself. As far as this study is concerned, most consumers prefer products that have G\&S recognition as they feel that the products are safe to consume and are hygienic.

This study is initially done to encourage Malaysian authorities to implement G\&S practices for the livestock sector. This study offers a comprehensive protocol in G\&S practices in food production and management. This criterion in G\&S is an initiative to transfer knowledge in developing a holistic guideline for livestock, and is important to the development of sustainable halal livestock; the drawing up of animal welfare acts in Malaysia; including agricultural and environmental policies. Indepth research on bio-economics and sustainable sourcing is needed as this study does not provide science-based research on breeding and animal research.

\section{Acknowledgements}

The author(s) extend their gratitude to Associate Professor Dr Chew Boon Cheong and Associate Professor Dr Mohd Syaiful Rizal Abdul Hamid for their guidance during this study. This research has been funded by the Ministry of Education under the Fundamental Research Grant Scheme number F00182. This study is part of a dissertation that was submitted as a partial fulfilment to meet the requirements of the degree of Doctor of Philosophy at Universiti Teknikal Malaysia Melaka.

\section{References}

Abu Dardak, R. (2015). Transformation of Agricultural Sector in Malaysia Through Agricultural Policy, 1-7. Retrieved from http://ap.fftc.agnet.org/ap db.php?id=386\&print=1

Ali, M. H., \& Suleiman, N. (2016). Sustainable food production: Insights of Malaysian halal small and medium sized enterprises. International Journal of Production Economics, 181, 303-314. https://doi. org/10.1016/j.ijpe.2016.06.003

Association of Poultry Processors and Poultry Trade in the EU Countries (AVEC). (2016). 2016 Annual Report. Brussels.

Battaglia, D. (2014). Animal Welfare at the Heart of Sustainability. Retrieved from http://www.fao.org/ag/againfo/home/en/ news_archive/2014_Animal_Welfare_at the Heart_of_Sustainability.html

Burch, D., Lyons, K., \& Lawrence, G. (2006). What Do We Mean by 'Green'? Consumers, Agriculture and the Food Industry. In Rikka rokassa vai sattumia sopassa? Johdatus yhteiskuntatieteelliseen maatalous-ja elintarviketutkimukseen (pp. 69-87). Helsinki,Finland: University of Joensuu,Karelian Institute.

Chen, Y., \& Chang, C. (2013). Towards green trust: the influence of green perceived quality, green perceived risk and green satisfaction. Management Decision, 51(1), 63-82. https://doi. org/10.1108/00251741311291319

Cheng, C. K. S. (2016). MyGAP From The Perspective of Livestock Industry --What, Why , How and When ? Malaysia: Federation of Livestock Farmers' Association of Malaysia.

Chin, O. T. (2017). Poultry Industry in Malaysia - An Overview. Retrieved September 13, 2018, from http://aer.global/topic-24poultry-industry-in-malaysia-an-overview/

Department of Veterinary Services. (2016). MALAYSIA : PENGGUNAAN PER KAPITA 
HASILAN TERNAKAN , 2007-2016. Retrieved from http://www.dvs.gov.my/ dvs/resources/user_1/DVS pdf/Perangkaan 2015 2016/page_10.pdf

Devendra, C. (2015). Improved feed technologies for expanding the productivity frontiers in Asia: The importance of system perspectives for transforming waning animal-agriculture. Animal Nutrition and Feed Technology. https://doi. org/10.5958/0974-181X.2015.00034.7

Dicks, L. V., Bardgett, R. D., Bell, J., Benton, T. G., Booth, A., Bouwman, J., ... Sutherland, W. J. (2013). What do we need to know to enhance the environmental sustainability of agricultural production? A prioritisation of knowledge needs for the UK food system. Sustainability (Switzerland), 5(7), 30953115. https://doi.org/10.3390/su5073095

Ecovadis. (2017). What is Sustainable sourcing. Retrieved from http://www.ecovadis.com/ sustainable-sourcing/

Elsedig, E. A. A., Mohd, M. I., \& Fatimah, M. A. (2015). Assessing the competitiveness and comparative advantage of broiler production in Johor using policy analysis matrix. International Food Research Journal, 22(1), 116-121.

European Environment Agency. (2011). Industry.

Evans, A., \& Syed, S. (2015). From niche to mainstream - Halal Goes Global. International Trade Centre. Geneva: International Trade Centre 2015. Retrieved from http://search.proquest.com.ezaccess. library.uitm.edu.my/docview/224324915?a ccountid $=42518$

Ezeh, C. I., Anyiro, C. O., \& Chukwu, J. A. (2012). Technical Efficiency in Poultry Broiler Production in Umuahia Capital Territory of Abia State, Nigeria. Greener Journal of Agricultural Sciences, 2(1), 1-7.

Federation of Livestock Farmers' Associations of Malaysia. (2016). Industry Overview. Retrieved September 13, 2018, from http:// flfam.org.my/index.php/industry-info/ industry-overview

Frazer, L. (2008, November). Green Screen for Poultry Farms. Environews.

Garnett, T. (2013). Food Sustainability: Problems, Perspectives and Solutions. In The Proceedings of the Nutrition Society (Vol. 72, pp. 29-39). King's College Conference Centre,University of Aberdeen. https://doi. org/10.1017/S0029665112002947

Goebel, P., Reuter, C., Pibernik, R., \& Sichtmann, C. (2012). The influence of ethical culture on supplier selection in the context of sustainable sourcing. International Journal of Production Economics, 140(1), 7-17. https://doi.org/10.1016/j.ijpe.2012.02.020

Hashim, F. A. H. (2015). Strategies to strengthen livestock industry in Malaysia. Malaysian Agricultural Research and Development Institute (MARDI), 1-6. Retrieved from http://ap.fftc.org.tw/ap_db.php?id=477

Leip, a, Billen, G., Garnier, J., Grizzetti, B., Lassaletta, L., Reis, S., ... Westhoek, H. (2015). Impacts of European livestock production: nitrogen, sulphur, phosphorus and greenhouse gas emissions, land-use, water eutrophication and biodiversity. Environmental Research Letters, 10(11), 115004. https://doi.org/10.1088/17489326/10/11/115004

Logaa, S. M. J., \& Zailani, S. (2013). Motives in implementing Green Productivity among EMS 14001 certified companies in Malaysia. African Journal of Business Management, 7(38), 3914. https://doi. org/10.5897/AJBM10.478

Luning, P. A., \& Marcelis, W. J. (2009). A food quality management research methodology integrating technological and managerial theories. Trends in Food Science and Technology, 20(1), 35-44. https://doi. org/10.1016/j.tifs.2008.09.013

Makkar, H. P. S. (2016). Towards zero waste and sustainable food production using humaninedible agroproducts and food loss and 
waste as animal feed Sustainable value chains for sustainable food systems. A workshop of the FAO / UNEP Programme on Sustainable Food Systems. Sustainble Value Chains for Sustainble Food Systems, (December), 29-39. https://doi.org/ISBN 978-92-5-109532-4 97

Makutenienė, D., \& Baležentis, T. (2015). The trends of technical, environmental and resource efficiency across agricultural sectors of european countries. Management Theory and Studies for Rural Business and Infrastructure Development, 37(2), 241251. https://doi.org/10.15544/mts.2015.22

Martin, G. B., \& Kadokawa, H. (2006). "Clean, green and ethical" animal production. Case study: reproductive efficiency in small ruminants. The Journal of Reproduction and Development, 52(1), 145-152. https://doi. org/http://dx.doi.org/10.1262/jrd.17086-2

Meullenet, J. (2013). The Role of Food Science in Food Systems research and Education. Arkansas Association for Food Protection.

Ministry of Agriculture. (2010). Third National Agricultural Policy (19982010). Putrajaya, Malaysia: Prime Minister's Office. Retrieved from http:// www.pmo.gov.my/dokumenattached/ D a s a r/29 THIR D_N AT I O N A L _ AGRICULTURAL_POLICY_(1998_2010)_-_EXECUTIVEE_SUMMARY.pdf

Mirza, S. K., Asema, U. K., \& Sultan Kasim, S. (2017). To Study The Harmful Effects Of Food Preservatives On Human Health. Journal of Medicinal Chemistry and Drug Discovery, 2(2), 610-616.

Murdoch, B. M., Murdoch, G. K., Greenwood, S., \& McKay, S. (2016). Nutritional influence on epigenetic marks and effect on livestock production. Frontiers in Genetics, 7(OCT). https://doi.org/10.3389/ fgene.2016.00182

Nazmi, M. S., M.A, M. Z., \& H.I, H. (2015). Broiler Industry in Malaysia. Retrieved
April 21, 2016, from http://ap.fftc.agnet. org/ap_db.php?id=532

Nizamuddin, Q. (2014). OIE Animal Welfare Standards and the Malaysian Animal Welfare Strategy: Achievements and Challenges. Department of Veterinary Services Malaysia.

Olesen, I., Groen, A. F., \& Gjerde, B. (2000). Definition of animal breeding goals for sustainable production systems. Journal of Animal Science, 78(3), 570-582. https:// doi.org//2000.783570x

Oosterveer, P., \& Sonnenfeld, D. A. (2012). Food, globalization and sustainability. Food, Globalization and Sustainability. London: Earthscan from Routledge.

Pacholewicz, E., Sura Barus, S. A., Swart, A., Havelaar, A. H., Lipman, L. J. A., \& Luning, P. A. (2016). Influence of food handlers' compliance with procedures of poultry carcasses contamination: A case study concerning evisceration in broiler slaughterhouses. Food Control, 68(August), 367-378. $\quad \mathrm{https}: / /$ doi.org/10.1016/j. foodcont.2016.04.009

Pereira, R. N., \& Vicente, A. A. (2010). Environmental impact of novel thermal and non-thermal technologies in food processing. Food Research International, 43(7), 1936-1943. https://doi.org/10.1016/j. foodres.2009.09.013

Power, G., Gardaz, A., \& Dey, J. (2012). Scaling up- Global Food Security and Sustainable Agriculture. New York: United Nations Global Compact.

Rabu, M. R., Rozana, N., Mohd, N., \& Shah, M. D. (2016). Malaysian Agricultural Quality Standards. FFTC Agricultural Policy Platform, 671, 1-9. Retrieved from http:// ap.fftc.agnet.org/ap_db.php?id=628

Reynolds, L. P., Wulster-radcliffe, M., Aaron, D. K., \& Davis, T. A. (2015). Importance of Animals in Agricultural Sustainability and Food Security. The Journal of Nutrition, 2-4. https://doi.org/10.3945/jn.115.212217 
Röös, E., Bajželj, B., Smith, P., Patel, M., Little, D., \& Garnett, T. (2017). Greedy or needy? Land use and climate impacts of food in 2050 under different livestock futures. Global Environmental Change, 47(January), 1-12. https://doi. org/10.1016/j.gloenvcha.2017.09.001

Ross, R. B., Pandey, V., \& Ross, K. L. (2015). Sustainability and Strategy in U.S. AgriFood Firms: An Assessment of Current Practices. International Food and Agribusiness Management Review (Vol. 18).

Sharaai, A. H., Samsuddin, N. S., \& Ismail, M. M. (2015). Sustainability of Chicken Meat Production in Achieving Food Security in Malaysia. Advances in Environmental Biology, 9(923), 1-6. Retrieved from http:// www.aensiweb.com/AEB/

Shen, J., Cui, Z., Miao, Y., Mi, G., Zhang, H., Fan, M., ... Zhang, F. (2013). Transforming agriculture in China: From solely high yield to both high yield and high resource use efficiency. Global Food Security, 2(1), 1-8. https://doi.org/10.1016/j.gfs.2012.12.004

Sonigo, P., Bain, J., Tan, A., Mudgal, S., MurphyBokern, D., Shields, L., ... Kastner, T. (2012). Assessment of resource efficiency in the food cycle. Final Report, ENV.G.4/ $F R$ (December). Retrieved from http://www. narcis.nl/publication/RecordID/oai:dare. ubvu.vu.nl:1871/39430

The Poultry Site. (2017). DPM: Malaysia Aims to Export $30 \%$ of Broiler Chickens by 2030. Retrieved September 14, 2018, from http://www.thepoultrysite.com/ poultrynews/39514/dpm-malaysia-aims-toexport-30-of-broiler-chickens-by-2030/

Tilman, D., Cassman, K. G., Matson, P. A., Naylor, R., \& Polasky, S. (2002, August). Agriculture sustainability and intensive production practices. Nature Publishing Group, 418(August), 671-677. Retrieved from www.nature.com/nature
Vaarst, M., Steenfeldt, S., \& Horsted, K. (2015). Sustainable development perspectives of poultry production. World's Poultry Science Journal, 71(4), 609-620. https://doi. org/10.1017/S0043933915002433

Van Kernebeek, H. R. J., Oosting, S. J., Van Ittersum, M. K., Bikker, P., \& De Boer, I. J. M. (2016). Saving land to feed a growing population: consequences for consumption of crop and livestock products. International Journal of Life Cycle Assessment, 21(5), 677-687. https://doi.org/10.1007/s11367015-0923-6

W.Blevins, P. (2013). Food Safety Regulatory Compliance: Catalyst for a Lean and Sustainable Food Supply Chain. CRC Press.

Watson, G., \& Schlotzer, A. (2017). Animals. Retrieved May 18, 2017, from http://greens. org.au/policies/animals

Westhoek, H., Ingram, J., Van Berkum, S., Ozay, L., \& Hajer, M. (2016). Introducing the food systems concept. Retrieved February 20, 2018, from https://www.futurelearn.com/ courses/food-systems-southeast-asia/1/ steps $/ 107660$

White, W., Lunnan, A., Nybakk, E., \& Kulisic, B. (2013). The role of governments in renewable energy: The importance of policy consistency. Biomass and Bioenergy, 57(October 2013), 97-105. https://doi. org/10.1016/j.biombioe.2012.12.035

Workman, D. (2018). Chicken Exports by Country. Retrieved September 13, 2018, from http://www.worldstopexports.com/ chicken-exports-by-country/

Zikeli, S., Rembialkowska, E., Zalecka, A., \& Badowski, M. (2014). Organic Farming and Organic Food Quality: Prospects and Limitations. In W. . Campbell \& S. L. Ortiz (Eds.), Sustainable Food Production Includes Human and Environmental Health (Vol. 3, pp. 85-165). Springer Science. https://doi.org/10.1007/978-94-007-7454-4 